\title{
WYDAWNICTWA
}

Recenzje i noty

\section{Jerzy Besala, Miłość i strach. Dzieje uczuć kobiet i mężczyzn, tom I, Wydawnictwo Zysk i S-ka, Poznań 2010, ss. 491}

Dzieje miłości, uczuć, czyli tego, co raczej mieściło się do niedawna jedynie w sferze zainteresowań psychologów, względnie psychiatrów, nareszcie stały się także źródłem zainteresowań historyków. Niebagatelną w tym rolę odegrały zapewne przemiany w badaniach historycznych zapoczątkowane jeszcze w ubiegłym wieku przez francuskich, a zaraz potem i anglosaskich dziejopisów.

W środowisku polskich historyków taka tematyka nie jest jeszcze popularna, tym bardziej zatem na uwagę zasługuje praca Jerzego Besali, zatytułowana: Miłość i strach. Dzieje uczuć kobiet i mężczyzn. Ukazała się ona w 2010 r. dzięki staraniom Wydawnictwa Zysk i S-ka.

Wybór takiej tematyki przez Jerzego Besalę nie jest zaskoczeniem. Badacz ten i dziennikarz w jednej osobie (współpraca z „Wiedzą i Życiem” oraz „Polityką”) zasłynął już jako autor trzytomowej pracy o małżeństwach polskich królów, a i jego liczne artykuły popularnonaukowe często właśnie oscylują wokół tej tematyki. O książce tej jednak i tak należy opowiedzieć osobno. Dlaczego?

Praca Jerzego Besali warta byłaby refleksji i lektury już z racji podjętej ogólnej tematyki. Szczegóły są równie ciekawe i zaskakujące. Przede wszystkim z tego powodu, że autor książki przełamał tabu podwójnie i zajął się rekonstrukcją narodzin uczuć w cywilizacjach dotąd słabo poznanych i obecnych w obowiązującej europocentrycznej wersji historii. Zajął się w swoich badaniach tematyką zgoła egzotyczną.

Prezentowana praca składa się z sześciu rozdziałów. Pierwszy z nich wprowadza czytelnika w tematykę i nosi tytuł: „Narodziny uczuć”. Jerzy Besala zadaje tu pytania: o sens pisania tego typu prac, o ich zawartość i wreszcie, czy istnieje zjawisko „walki płci”? Opisuje także paleolityczny „,złoty wiek” miłości i „,neolityczna rewolucję”. Rozdział kolejny to miłość i uczucia w cywilizacjach Wschodu, a zatem Mezopotamii, Indii, Chin, Wietnamu, Japonii, Korei, plemion arabskich, irańskich i tureckich. Rozdział trzeci to: „Cywilizacje Afryki”, kobieta i mężczyzna nad Nilem i wyrzezywanie uczuć na czarnym lądzie. Następnie opisuje sposoby obrony i rewanżu podejmowane przez kobiety Wschodu i Afryki wobec mężczyzn. Jerzy Besala rekonstruuje sferę uczuć w cywilizacji żydowskiej, poruszając między innymi takie zagadnienia, jak: model rodziny, tematy tabu, np.: 
homoseksualizm, starość, ale także: wzorce żydowskich kobiet, władczych i fatalnych, problem prostytucji. Ostatni rozdział został poświęcony cywilizacjom indiańskim: Inków, Majów i Azteków. Tradycyjnie w tej części pracy znalazł się fragment dotyczący siły i wpływów kobiet indiańskich, ich sposobów „czarowania” mężczyzn i sposobów pozyskiwania przez nie swoich stref wpływów. Uzupełnieniem publikacji jest wybrana (niestety!) literatura przedmiotu i dokładnie zestawiony indeks osób. Ponadto w pracy znalazły się kolorowe zdjęcia i ilustracje nawiązujące do problematyki książki.

Książka Jerzego Besali to przykład doskonałego sposobu popularyzowania wiedzy historycznej, zwłaszcza gdy duża część dziejopisów tematyki miłosnej do Historii, celowo pisanej przez duże „H”, nie zalicza. Nie mam więcej uwag.

Edyta Głowacka-Sobiech

\section{Dawne zabawy dziecięce, red. Dorota Źołądź-Strzelczyk, Kata- rzyna Kabacińska, Wydawnictwo DiG \& Muzeum Zabawek i Zabawy w Kielcach, Kielce-Warszawa 2008, ss. 72}

W 2008 r., nakładem Wydawnictwa DiG oraz Muzeum Zabawy i Zabawek w Kielcach, ukazała się książka Dawne zabawy dziecięce pod redakcją Doroty Żołądź-Strzelczyk i Katarzyny Kabacińskiej. Publikacja ta jest wyrazem zainteresowań naukowych Autorek, których tematyka badawcza koncentruje się na dzieciństwie w dawnych czasach oraz, jak sam tytuł wskazuje, dawnych zabawach i zabawkach dziecięcych. Do współpracy Autorki zaprosiły Ryszarda Kantora oraz dyrektor Muzeum Zabawek i Zabawy w Kielcach - Jolantę Podsiadło, którzy to swoimi tekstami dotyczącymi problematyki zabawy stworzyli swoiste jej podsumowanie.

Bazę źródłową publikacji stanowi dzieło Łukasza Gołębiowskiego Gry i zabawy różnych stanów kraju całym, lub niektórych tylko prowincjach wydane w Warszawie, w 1831 r. To z niego pochodzą opisy zabaw przedstawionych w książce, ale nie tylko. Opisy pochodzą również z dzieł Sebastiana Petrycego czy Jędrzeja Kitowicza, a także z utworów literackich oraz tekstów z czasopism XIX w., takich jak „Kronika Rodzinna” czy „Przyjaciel Dzieci”. Publikację tę, wyróżniają jednak nie tylko szczegółowe opisy zabaw dziecięcych, lecz przede wszystkim obszerna baza ilustracji, która pomaga czytelnikowi w dokonaniu wizualizacji omawianej zabawy. I tak, znajdziemy tutaj ilustracje zaczerpnięte z XIX-wiecznych czasopism, takich jak „Przyjaciel Dzieci”, „Świat Ilustrowany”, „Kłosy”, a także rysunki Daniela Chodowieckiego i Michała Stachowicza.

Na rozważania merytoryczne, poparte ilustracjami, składa się pięć części książki. Już na wstępie zostaje przedstawiona geneza owej publikacji. Książka zawiera opis 27 zabaw, z wyłączeniem zabaw słownych czy umysłowych, które zajmowały wolny czas dzieci na ziemiach polskich do XIX w. włącznie. Pedagogiczno-historyczny charakter publikacji 